\title{
Pengaruh Penggunaan Limbah Kubis dalam Silase Ransum Komplit Berbasis Limbah Tebu Terhadap Kecernaan Bahan Kering, Bahan Organik, dan VFA Secara In vitro
}

\author{
Adika Sugara ${ }^{1, a}$, Adrizal ${ }^{2}$, Irsan Ryanto ${ }^{2}$ \\ ${ }^{1}$ Program Studi S2 Ilmu Peternakan Pascasarjana Fakultas Peternakan Universitas Andalas \\ ${ }^{2}$ Bagian Nutrisi dan Teknologi Pakan, Fakultas Peternakan Universitas Andalas \\ aemail: adikasugara.phoenix@gmail.com
}

\begin{abstract}
Abstrak
Penelitian ini bertujuan untuk mengetahui kecernaan bahan kering, bahan organik, dan kandungan Volatile Fatty Acid (VFA), serta mengetahui persentase penggunaan limbah kubis sebagai sumber protein terbaik pada silase ransum komplit berbasis limbah tebu secara in vitro. Metode penelitian yang digunakan yaitu Rancangan Acak Kelompok yang terdiri atas 4 perlakuan dan 4 kelompok pengambilan cairan rumen sebagai ulangan. Perlakuan pada penelitian ini dengan menggunaan limbah kubis dengan level yang berbeda yaitu $0 \%, 5 \%, 10 \%$ dan $15 \%$ pada silase ransum komplit berbasis limbah tebu. Hasil analisis keragaman menunjukan bahwa penggunaan limbah kubis sebagai sumber protein pada silase ransum komplit berbasis limbah tebu berpengaruh nyata $(\mathrm{P}<0,05)$ terhadap kecernaan bahan kering, bahan organik, dan VFA. Persentase penggunaan limbah kubis sebagai sumber protein terbaik pada perlakuan dengan penambahan $10 \%$ limbah kubis. Hasil yang diperoleh dari penelitian ini yaitu kecernaan bahan kering 43.97\%, kecernaan bahan organik 47.83\%, dan Kandungan VFA 149.85 mM. Kata Kuci: limbah kubis, limbah tebu, bahan kering, bahan organik, VFA
\end{abstract}

\section{Effects of The use of Cabbage Weste in Sugarcane-Based Complete Ration Silage on The Digestibility Of Dry Matter, Organic Matter And VFA In vitro}

\begin{abstract}
This study aims to determine the digestibility of dry matter, organic matter, VFA content and determine the percentage of cabbage waste use as the best source of protein in sugarcane-based complete ration silage in vitro. The research method used was a randomized block design consisting of 4 treatments and 4 groups taking rumen fluid as a test. The treatment in this study was the use of cabbage waste with different levels namely $0 \%, 5 \%, 10 \%$ and $15 \%$ in complete ration based on sugarcane waste. The results of the analysis showed that the use of cabbage waste as a protein source in complete ration based sugarcane waste significantly affected $(P<0.05)$ the digestible of dry matter organic matter.and VFA. The percentage of cabbage waste use as the best source of protein in with an additional percentage $10 \%$ of cabbage. The results obtained were $43.97 \%$ dry matter digestibility, 47.83\% organic matter digestibility, and 149. $85 \mathrm{mM}$ VFA content.
\end{abstract}

Keyword: Cabbage waste, Sugarcane waste, Dry matter, Organic matter, VFA 


\section{Pendahuluan}

Keberhasilan dalam usaha peternakan sangat tergantung pada pakan yang digunakan. Pakan dalam usaha peternakan khususunya pemeliharaan ternak ruminansia harus tersedia secara kontinu, tidak bersaing dengan kebutuhan manusia, tidak bersifat racun, kandungan gizinya mencukupi dan memiliki kecernaan yang baik sehingga ternak mampu tumbuh dan berproduksi dengan baik pula. Sumber bahan pakan yang memenuhi syarat seperti ini sebagian besar berasal dari limbah pertanian dan limbah perkebunan.

Secara umum, limbah pertanian dan perkebunan belum mampu dimanfaatkan secara langsung untuk pakan ternak ruminansia, hal ini dikarenakan kandungan nutrien yang rendah, nilai kecernaan yang masih relatif rendah, dan faktor anti nutrisi lainya yang dapat menggangu pencernaan ternak ruminansia. Selain zat yang terkandung di dalam limbah tersebut juga dikhawatirkan zat kimia yang berasal dari luar seperti penggunaan pestisida secara berlebihan sehingga perlu dilakukan pengolahan dan perlakuan lebih lanjut.

Indonesia merupakan negara agraris yang secara umum masyarakatnya hidup dengan bercocok tanam untuk memenuhi kebutuhan hidupnya. Selain itu, masyarakat Indonesia menjadikan ternak sebagai usaha sampingan seperti beternak sapi, kerbau kambing dan domba. Kondisi ini menggambarkan bahwa ketersediaan limbah pertanian sangat berlimpah dan belum bisa dimanfaatkan secara optimal.

Limbah pertanian yang berlimpah jika dibiarkan akan menimbulkan masalah baru yang dapat mencemari lingkungan sekitarnya serta bersifat musiman sehingga perlu dilakukan pengawetan dan penyimpanan agar limbah tersebut tersedia secara terus menerus dan tidak bergantung pada kondisi alam dan dapat digunakan sebagai pakan ternak seperti ternak sapi atau ternak kerbau secara kontinu.

Populasi ternak kerbau di Sumatera Barat beberapa tahun terakhir terjadi penurunan yang signifikan. Populasi ternak kerbau pada tahun 2013 sebesar117.905 ekor (Direktorat Jendral Peternakan dan Kesehatan Hewan, 2013) dan kemudian terjadi penurunan menjadi 110.236 ekor pada tahun 2017 (BPS Sumatera Barat, 2019). Penurunan populasi ini diduga disebabkan karena berkurangnya lahan pengembalaan akibat dari peralihan untuk sehingga ketersediaan pakan semakin berkurang dan semakin hari akan mengancam habitat ternak kerbau sebagaimana yang dapat dilihat bahwa sebagian besar sistem pemeliharaannya masih menerapkan sistem tradisional.

Melihat kondisi ini perlu dilakukan pemeliharaan yang intensif dengan memanfaatkan limbah pertanian dan perkebunan yang masih tersedia sangat banyak. Limbah perkebunan tebu yang terdiri atas pucuk tebu, ampas tebu dan molases yang berasal dari cairan sisa penggilingan tebu bisa digunakan untuk pakan ternak kerbau. Pucuk tebu dapat kita kategorikan sebagai daun yang terdapat pada ujung atas batang tebu lebih kurang 5 sampai 6 helai pada batang tebu yang dipotong untuk digiling. Adrizal et al. (2014) melaporkan bahwa 91\% dari tanaman tebu merupakan limbah dan belum bisa dimanfaatkan secara optimal untuk kebutuhan ternak.

Limbah tebu memiliki kandungan nutrien yang baik sebagai bahan pakan ternak. Adrizal et al. (2014) melaporkan kandungan limbah ampas tebu adalah Bahan Kering (BK) $33.60 \%$, Protein Kasar (PK) $2.72 \%$, Serat Kasar (SK) 24,20\%, Lemak Kasar (LK) 1,30\% dan Bahan Ekstrak Tanpa Nitrogen (BETN) $60,40 \%$ dan pucuk tebu BK $26,40 \%$, PK $8,49 \%$, SK $34,50 \%$, LK 2,90\% dan BETN 44,70\%.

Data penelitian sebelumnya menunjukkan bahwa potensi limbah tebu sangat baik digunakan sebagai bahan pakan ternak kerbau karena mengandung serat kasar yang tinggi sebagaimana ternak ruminansia memiliki kemampuan mencerna serat kasar dengan baik. Namun, kandungan protein masih belum memenuhi kriteria bahan pakan yang baik sehingga perlu dicarikan bahan pakan sumber protein sehingga kebutuhan kerbau tercukupi. Bahan pakan sumber protein yang memungkinkan digunakan adalah limbah pertanian berupa limbah kubis.

Limbah kubis merupakan limbah pertanian yang memiliki potensi yang cukup baik dilihat dari kandungan nutrisi yang cukup tinggi dan ketersediaannya yang berlimpah. Kandungan limbah kubis yang sudah dianalisa pada Laboratorium Nutrisi Ternak Ruminansia Fakultas Peternakan Universitas Andalas didapatkan PK 22,47\%, LK 3.05\%, SK 12.09\%, BK $10.22 \%$ dan BETN 34.96\%. Data tersebut menunjukan tingginya kandungan protein yang terdapat dalam limbah kubis sehingga perlu dimanfaatkan secara maksimal agar limbah tersebut tidak terbuang secara percuma. 
Pemanfaatan limbah kubis secara langsung dikwatirkan dapat menganggu kesehatan ternak karena kandungan air yang sangat tinggi yaitu sekitar 92,44 \% (Muktiani et al., 2007). Faktor lain yang tak kalah pentingnya adalah palatabilitas dari limbah tersebut juga menentukan keberhasilan dalam pemanfaatan limbah tersebut sebagaimana limbah kubis dalam keadaan segar memiliki aroma yang khas dan tidak disukai oleh ternak kerbau. Untuk mengatasi beberapa kendala dalam pemanfaatan limbah pertanian dan perkebunan perlu dilakukan pengawetan dan peningkatan kualitas bahan pakan tersebut melalui pembuatan silase ransum komplit yang berbasis limbah tebu dan limbah kubis.

Silase adalah produk dari awetan hijauan yang berkadar air tinggi dengan menggunakan mikroorganisme yang bersifat aerob dan disimpan dalam kondisi anaerob (Woolford, 1984). Formula ransum yang berbasiskan limbah kubis dan limbah tebu dengan persentase yang berbeda dan penyimpanan dalam bentuk silase tentu akan memberikan pengaruh yang bervariasi terhadap nilai kecernaan pada ternak kerbau, namun sampai sejauh mana pengaruhnya belum diketahui secara pasti. Untuk membuktikan Sampai sejauh mana pengaruh terhadap nilai kecernaannya dan batas persentase penggunaan limbah tersebut, maka perlu dilakukan penelitian secara mendalam pada ternak kerbau secara In vitro.

In vitro menurut Tilley dan Terry, (1963) adalah salah satu metoda dalam mengevaluasi pakan ternak dengan menggunakan analisa kimia di laboratorium (AOAC, 1984), untuk memprediksi yang terjadi pada proses pencernaan sebenarnya pada ternak ruminansia. Ismartoyo (2011) menambahkan bahwa metode ini dapat menirukan proses yang terjadi sebenarnya dalam pencernaan ruminansia.

\section{Materi Dan Metode Materi Penelitian}

Materi yang digunakan dalam Penelitian ini adalah limbah kubis, silase ransum komplit, cairan rumen kerbau sebagai sumber mikroba, bahan kimia yang digunakan untuk analisa proksimat dan Van Soest serta larutan McDougall's sebagai buffer.

\section{Rancangan Penelitian}

Rancangan yang digunakan adalah rancangan acak kelompok $4 \times 4$ dengan 4 macam formulasi silase ransum komplit sebagai perlakuan dan 4 kelompok pengambilan cairan rumen sebagai ulangan. Perlakuan adalah penggunaan limbah kubis dengan level yang berbeda yaitu $0 \%, 5 \%, 10 \%$ dan $15 \%$ pada silase ransum komplit berbasis limbah tebu. Perbedaan nilai tengah perlakuan dilanjutkan dengan pengujian DMRT (Duncan's Multiple Range Test).

\section{Prosedur Penelitian}

Pembuatan silase ransum komplit dilakukan dengan cara melayukan limbah kubis dan limbah tebu selama 12 jam menggunakan sinar matahari dan setelah itu dicincang menggunakan mesin coper sampai berbentuk serabutan. Setelah bahan bahan penyusun ransum sudah lengkap, bahan bahan tersebut ditimbang sesuai formulasi yang sudah disusun kemudian semua bahan dicampur menggunakan mixer. Setelah semua bahan tercampur kemudian dimasukan kedalam karung yang sudah dilapisi palstik dan divakum menggunakan vakum pump agar udara tidak masuk kedalam karung yang sudah berisi ransum komplit. Setelah semua udara yang ada didalam karung hilang, karung tersebut diikat dan disimpan selama 3 minggu agar bisa digunakan.

\section{Tempat Penelitian}

Penelitian ini dilakukan Di Laboraturium Ruminansia dan Bioteknologi Fakultas Peternakan Universitas Andalas dan Nagari Talang Babungo Kecamatan Hiliran Gumanti Kabupaten Solok.

\section{Peubah yang diamati}

\section{Kecernaan Bahan Kering}

Pengukuran kecernaan bahan kering didapatkan dengan cara mengukur kandungan bahan kering bahan dengan cara mencari kandungan air bahan tersebut. Kadar air didapatkan dengan cara mengoven bahan pada suhu $105^{\circ} \mathrm{C}$ selama 1 jam dan didinginkan dalam desikator selama 15 Menit dan ditimbang. Kecernaan bahan kering diuji dengan cara menimbang sampel \pm 2 gram, kemudian masukan kedalam cawan porselin dan dioven pada suhu $105^{\circ} \mathrm{C}$ selama 8 jam.

\section{Kecernaan Bahan Organik}

Pengukuran kecernaan bahan organik terlebih dahulu menentukan kandungan bahan organik. Bahan organik terdiri atas protein, 
lemak, serat kasar dan BETN yang mampu menghasilkan energi yang bermanfaat. Zat anorganik hanya terdiri atas abu setelah bahan dipanaskan pada suhu $600^{\circ} \mathrm{C}$. Bahan organiknya teroksidasi menjadi karbon dioksida dan air (Sutardi, 1980). Kandungan serat kasar masing masing perlakuan adalah A $21,08 \%$, B 20,42\%, C 20,40\% dan D 20,71\%. Sementara kandungan lignin pada masing masing perlakuan berturut turut adalah $\mathrm{A}(2,45 \%), \mathrm{B}(1,46 \%), \mathrm{C}(3,54 \%)$ dan $\mathrm{D}(3,78 \%)$.

Kandungan bahan organik (BO) didapatkan dengan terlebih dahulu melakukan kadar abu dengan cara memasukan dalam tanur pada temperatur $600^{\circ} \mathrm{C}$ selama 6 jam. Setelah berada didalam tanur selama 6 jam, matikan tanur dan tunggu suhunya turun mencapai $200^{\circ} \mathrm{C}$ kemudian sampel diambil dan dimasukan kedalam desikator selama 1 jam, setelah itu baru ditimbang.

\section{Kandungan VFA}

Konsentrasi VFA ditentukan dengan metode steam destilasi (General Laboratory Procedures, 1966). Pengukuran VFA dilakukan menggunakan sampel sebanyak $5 \mathrm{ml}$ dan $1 \mathrm{ml}$ $\mathrm{H}_{2} \mathrm{SO}_{4} 15 \%$ kemudian dimasukan kedalam alat destilasi. Kemudian Cairan ditampung sekitar 250- $300 \mathrm{ml}$ dan dititrasi dengan larutan $\mathrm{HCl}$ $0,5 \mathrm{~N}$.

\section{Rancangan Percobaan}

Rancangan yang digunakan adalah rancangan acak kelompok 4 x 4 dengan 4 jenis persentase penggunaan limbah kubis dengan level yang berbeda dalam silase ransum komplit sebagai perlakuan dan 4 kelompok pengambilan cairan rumen kerbau sebagai ulangan. Perlakuan yaitu pemakaian limbah kubis dengan taraf berbeda yaitu $0 \%, 5 \%, 10 \%$ dan $15 \%$ pada silase ransum komplit berbasis limbah tebu. Model matematis dari rancangan yang digunakan sesuai dengan rancangan menurut Steel and Torrie (1995).

\section{Hasil dan Pembahasan \\ Kecernaan Bahan Kering}

Hasil Penelitian penggunaan limbah kubis pada silase ransum komplit didapatkan pengaruh nyata terhadap kecernaan bahan kering secara in vitro. Tabel 1 menunjukan persentase pada masing masing perlakuan dengan menggunakan uji lanjut DRMT (Duncan's Multiple Range Test) pada taraf 5\%.

Tabel 1 menunjukkan rataan kecernaan bahan kering secara in vitro berkisar antara $40,36 \%-44,73 \%$, dimana terdapat kecernaan bahan kering tertinggi disetiap perlakuan terdapat pada perlakuan B yaitu $44.73 \%$ dan yang terendah terdapat pada perlakuan $D$ yaitu 40,36\%. Hal ini menunjukkan bahwa penggunaan limbah kubis di dalam silase ransum komplit berbasis limbah tebu memberikan pengaruh nyata terhadap kecernaan bahan kering secara In vitro.

Hasil penelitian dari keempat perlakuan tersebut menunjukan bahwa kecernaan bahan kering terbaik terdapat pada perlakuan B yaitu $44,73 \%$ jika dibandingkan dengan pada perlakuan C 43,97 \% dan Perlakuan D 40,36\% dan perlakuan A sebagai kontrol tidak berebeda jauh dengan perlakuan $\mathrm{C}$.

Hasil kecernaan yang berbeda dari setiap perlakuan diduga disebabkan kandungan serat kasar masing masing perlakuan adalah A $21,08 \%$, B $20,42 \%$, C $20,40 \%$ dan D $20,71 \%$ yang terdapat dalam silase ransum komplit berbasis limbah tebu yang sebagian besar disumbangkan oleh limbah tebu. Anggorodi (1979) menjelaskan bahwa dalam penelitiannya semakin banyak serat kasar dalam bahan pakan, maka dinding sel semakin menebal dan tahan terhadap mikroorganisme pencerna serat yang berdampak semakin rendahnya daya cerna bahan tersebut. Serat dalam bahan pakan sangat dipengaruhi oleh NDS dan NDF.

Tabel 1. Rataan Kecernaan Bahan Kering Secara In Vitro

\begin{tabular}{cc}
\hline Perlakuan & Rataan Kecernaan Bahan Kering (\%) \\
\hline A & $43,09^{\mathrm{a}}$ \\
B & $44,73^{\mathrm{a}}$ \\
C & $43,97^{\mathrm{a}}$ \\
D & $40,36^{\mathrm{b}}$ \\
\hline SE & 0,87 \\
\hline
\end{tabular}

Keterangan: superskrip yang berbeda pada kolom yang sama menunjukkan hasil yang berbeda nyata (P $<0,05)$ 
Kandungan NDF pada masing masing perlakuan adalah $\mathrm{A}(65,04 \%), \mathrm{B}(59,56 \%)$, $\mathrm{C}(70,04 \%)$ dan $\mathrm{D}(69,10 \%)$ yang cukup tinggi dan menyebabkan makin sulitnya untuk dicerna sehingga nilai kecernaan semakin rendah pula. Faktor lain yang diduga dapat mempengaruhi daya cerna mikroba rumen terhadap kandungan bahan kering adalah kandungan lignin yang terdapat dalam bahan tersebut. Hasil analisa kandungan lignin pada masing masing perlakuan berturut turut adalah $\mathrm{A}(2,45 \%)$, $\mathrm{B}(1,46 \%), \mathrm{C}(3,54 \%)$ dan $\mathrm{D}(3,78 \%)$.

Kandungan lignin yang tinggi pada bahan pakan penyusun silase ransum komplit berbasis limbah tebu bisa menyebabkan kecernaan bahan kering juga semakin rendah. Penelitian sebelumnya menyatakan bahwa lignin yang ada dalam bahan pakan dapat mengurangi kecernaan karbohidrat dengan pembentukan ikatan hidrogen dan selulosa serta hemiselulosa yang dapat membatasi enzim selulase untuk mencerna serat kasar ( Arora,1995) Penelitian yang dilakukan Tillman et al. (1998), juga menerangkan bahwa lignin bersama-sama selulosa membentuk komponen yang disebut lignoselulosa, yang mempunyai koefisien cerna sangat kecil.

Tingginya kandungan selulosa dalam ransum yang mana dengan adanya lignin dalam ransum akan berikatan dengan selulosa dan hemiselulosa sehingga dapat menurunkan kecernaan ransum. Jung (1989), menyatakan bahwa lignin merupakan penghambat kecernaan dinding sel tanaman sehingga semakin banyak lignin dalam dinding sel maka koefisien cerna hijauan juga semakin rendah. Ditegaskan oleh Zulharman (2010) bahwa tingginya komponen serat yang tidak dapat dicerna (lignin dan silika) dapat menyebabkan rendahnya kecernaan.

Kandungan liqnin yang tinggi pada silase ransum komplit berbasis limbah tebu dan limbah kubis diduga berasal dari limbah tebu. Samsusri et al., (2007) menjelaskan bahwa kandungan nutrien dari ampas tebu didapatkannya selulosa $52,7 \%$, hemiselulosa $20,0 \%$ dan kandungan lignin $24,25 \%$.

Penelitian lain menegaskan selulosa merupakan komponen struktural utama dinding sel, selulosa memiliki kekuatan mekanisnya yang sangat tinggi, tahan terhadap zat-zat kimia dan relatif tidak larut dalam air (Kusnandar, 2010). Data penelitian tersebut menguatkan bahwa yang dapat mempengaruhi nilai kecernaan bahan kering silase ransum komplit berbasih limbah tebu dan limbah kubis berasal dari kandungan lignin dan serat kasar yang sebagian besar disumbangkan oleh limbah tebu.

\section{Kecernaan Bahan Organik}

Hasil penelitian pengaruh penggunaan limbah kubis dalam silase ransum komplit terdapat pada Tabel 2. Hasil uji lanjut menggunakan DMRT (Duncan's Multiple Range Test) pada taraf 5\%.

Tabel 2 merupakan rataan hasil kecernaan bahan organik secara in vitro yaitu $44,55 \%$ $49,42 \%$. Kecernaan tertinggi terdapat pada perlakuan B yaitu $49,42 \%$ dan terendah pada perlakuan D sebesar 44,55\%. Hal ini menunjukkan bahwa penggunaan limbah kubis didalam silase ransum komplit berbasis limbah tebu memberikan pengaruh nyata terhadap kecernaan bahan organik secara in vitro.

Hasil penelitian menunjukan terjadinya pengaruh nilai kecernaan bahan organik pada setiap perlakuan. Hasil penelitian menunjukan kandungan bahan organik dari masing masing perlakuan berturut turut adalah $\mathrm{A}(92,38 \%)$, $\mathrm{B}(92,01 \%), \mathrm{C}(91,40 \%)$ dan $\mathrm{D}(91,10 \%)$. Dari data tersebut dapat dilihat bahwa kandungan bahan organik dari setiap perlakuan sangat tinggi, akan tetapi nilai kecernaan dari bahan organik tersebut berturut turut adalah perlakuan A $46,07 \%$, B $49,42 \%$, C 47,83\% dan D 44,55\%.

Rendahnya nilai kecernaan yang terdapat pada setiap perlakuan berkaitan dengan nilai kecernaan bahan kering dari bahan pakan tersebut. Komponen bahan organik terdiri atas serat kasar, protein, karbohidrat, lemak dan BETN. Sutardi (1982), menjelaskan bahwa degradasi bahan organik erat kaitannya dengan degradasi bahan kering, karena sebagian bahan kering terdiri atas bahan organik. Suardin et al. (2014) menambahkan, bahwa penurunan kecernaan bahan kering mengakibatkan kecernaan bahan organik menurun atau sebaliknya. 
Tabel 2. Rataan Kecernaan Bahan Organik Secara In Vitro

\begin{tabular}{cc}
\hline Perlakuan & Rataan Kecernaan Bahan Organik (\%) \\
\hline A & $46.07^{\mathrm{bc}}$ \\
B & $49.42^{\mathrm{a}}$ \\
C & $47.83^{\mathrm{ab}}$ \\
D & $44.55^{\mathrm{c}}$ \\
\hline SE & 0,94
\end{tabular}

Keterangan: superskrip yang berbeda pada kolom yang sama menunjukkan hasil yang berbeda nyata (P $<0,05)$.

\section{Kandungan Volatile Fatty Acid (VFA)}

Hasil kandungan VFA penggunaan limbah kubis dalam silase ransum komplit berbasis limbah tebu dapat dilihat pada Tabel 3.

Tabel 3. Rataan Kandungan VFA Secara In vitro

\begin{tabular}{cc}
\hline Perlakuan & Rataan Kandungan VFA (mM) \\
\hline A & $123,63^{\mathrm{b}}$ \\
B & $139,86^{\mathrm{a}}$ \\
C & $149,85^{\mathrm{a}}$ \\
D & $138,61^{\mathrm{ab}}$ \\
\hline SE & 4,50 \\
\hline
\end{tabular}

Keterangan: superskrip yang berbeda pada kolom yang sama menunjukkan hasil yang berbeda nyata (P $<0,05)$

Tabel 3 menunjukkan rataan kandungan VFA secara in vitro berkisar 123,63 - 144,86 $\mathrm{mM}$, dimana kandungan VFA tertinggi yaitu 144,86 mM pada perlakuan C dan yang terendah pada perlakuan A yaitu 123,63 mM.

Penelitian ini menunjukkan kandungan VFA tertinggi terdapat pada perlakuan $C$ yaitu 144,86 mM yang disebabkan oleh kemampuan mikroba rumen dalam mencerna protein dan serat kasar yang terkandung dalam silase ransum komplit berbasis limbah tebu. Angka ini masih berada pada posisi yang optimal untuk mendukung sintesis protein mikroba dalam rumen ternak kerbau. Sutardi (1980) menerangkan bahwa konsentrasi VFA dengan kisaran optimum untuk berlangsungnya sintesis protein mikroba yaitu sebesar $80-160 \mathrm{mM}$. Dilihat dari kandungan VFA yang ada dalam rumen dapat menunjukkan bahwa tingginya degradasi nutrien oleh enzim - enzim yang dihasilkan oleh mikroba dalam rumen. Meningkatnya jumlah mikroba akan memperbanyak gas - gas hasil metabolisme sehingga meningkatkan kandungan VFA cairan rumen.

Penelitian yang dilakukan oleh Mc Donald et al. (1989) menerangkan bahwa karbohidrat dalam rumen melewati dua tahap pencernaan oleh enzim-enzim yang dihasilkan oleh mikroba. Tahap pertama, karbohidrat dihidrolisis menjadi monosakarida dan selanjutnya, gula sederhana tersebut dipecah menjadi asam asetat, asam propionat, asam butirat, $\mathrm{CO}_{2}$, dan $\mathrm{CH}_{4}$ dan diserapnya VFA ke dalam sistem peredaran darah kemudian diubah oleh hati menjadi gula darah. Gula darah inilah yang sebagian besar menyuplai kebutuhan energi (Lehninger, 1982). Sutardi (1980) juga menjelaskan bahwa VFA merupakan bahan utama pembentukan protein mikroba.

\section{Kesimpulan}

Persentase penggunaan limbah kubis terbaik dalam silase ransum komplit berbasis limbah tebu secara In vitro terdapat pada perlakuan $\mathrm{C}$ dengan penambahan limbah kubis sebesar $10 \%$. Hasil yang diperoleh yaitu kecernaan bahan kering 43,97\%, kecernaan bahan organik $47,83 \%$ dan Kandungan VFA $149,85 \mathrm{mM}$.

\section{Daftar Pustaka}

Adrizal, Asmin A, Montesqrit. (2014). Commercialization of Sugar Cane Waste-Based Complex Silage Package with Vacuum Technology to Support the National Beef Self-Sufficiency Program. Final Report of Andalas University and Industrial Research. Padang, Andalas University

Anggorodi, R. (1979). General Animal Feed Science. PT. Gramedia. Jakarta 
Arora, S. P. 1995. Microbial Digestion in Ruminant Animals. Translator: R. Muwarni. Gajah Mada University Press, Yogyakarta

Ismartoyo. (2011). Introduction to Research Techniques: Ruminant Animal Degradation. Makassar. Brilliant International.

Jung, H. G. (1989). Forage lignins and their effect on feed digestibility. Agronomy Journal. 81 (1) : 33 - 38.

Kusnandar, F. (2010). Food Chemistry. Food Component PT dian Rakyat, Jakarta

Lehninger, A. L. (1982). Dasar-dasar Biokimia. Penerjemah : M. Thenawidjaja. Erlangga, Jakarta.

Mc Donald, P., Edwards, R. A., and Greenhalg, J. F. D. (1989). Animal Nutrition. 4th. English Language Book Society/Longman Group Ltd, Hongkong.

Mourino, F.R, Akkarawongsa P.J, Weimer. (2001). Initial pH As A Determinant Of Sellulose Digestion Rate By Mixed Ruminal Microorganisms In Vitro. $J$ Dairy Sci. 84: 848-859.

Muktiani, A., Tampoebolon, B.1.M., and Achmadi, I., (2007). In vitro rumen fermentability of processed vegetable waste. J. Tropical Animal Husbandry Development. 32 (m): 44-50.

Muhtarudin. (2007). Cane shoot digestion is processed in vitro. J. Indon. Trop. Anim. Agric Faculty of Agriculture, University of Lampung. Bandar Lampung. 32 (3), September 2007

Steel, R.G.D., and Torrie, J.H. (1995). Statistics Principles and Procedures. 4th edition.
Gramedia Pustaka Utama Publisher, Jakarta. (Translated by B. Sumantri).

Suardin, N. S. and Aka, R. (2014). Digestion of dry matter and organic material mixed with mulato grass (Brachiaria hybrid) $v$. Mulato) with different types of legumes using bovine rumen fluid. Faculty of Animal Husbandry. Halu Oleo University. Department of Tropical Animal Husbandry Science. 1 (1): 16-22.

Sutardi, T., Pratiwi, S.H., Adnan, A. and Nuraini, S. (1980). Increased Utilization of Rice Straw through Alkaline Hydrolysis, Urea Supplementation and Sulfur. Bull Cattle fodder. Bogor.

Sutardi, T. (1982). Dairy Cattle and Their Feeding. Dept. Animal Food Science, Faculty of Animal Husbandry, IPB. Bogor.

Tilley, J. M.A. and Terry, R.A. (1963). A two stage technique for the in vitro digestion of forage crop. J. British Grassland Society. 18: 104-111.

Tillman, A.D, Hartadi, H., Prawirokusumo, S., Reksohadiprodjo, S., dan Lebdosoekojo, S. (1998). Ilmu Makanan Ternak Dasar. Cetakan Ke-5. Gadjah Mada University Press, Yogyakarta.

Tjokroadikoesoemo, P. S. (1986). HFS and Other Cassava Industries. Gramedia Pustaka Utama, Jakarta.

Van Soest, P.J. (1982). Nutritional Ecology of The Ruminant. Commstock Publishing Associates. A devision of Cornell University Press. Ithaca and London.

Woolford,M.K. (1984). Biochemistry of Silage. John Willey and Sons, Chichester, NewYork. 